\title{
Higher Education Policy \& Research in Pakistan: Challenges in Transformation of the Society and the Way Forward
}

\author{
Noor Fatima ${ }^{1, *}$, Muhammad Imran Ashraf ${ }^{2}$, Sania Zehra ${ }^{1}$ \\ ${ }^{1}$ Department of International Relations and Political Science, International Islamic University, Pakistan \\ ${ }^{2}$ Department of International Relations, National Defence University, Pakistan
}

Received March 12, 2020; Revised May 1, 2020; Accepted May 13, 2020

Copyright $(2020$ by authors, all rights reserved. Authors agree that this article remains permanently open access under the terms of the Creative Commons Attribution License 4.0 International License

\begin{abstract}
Education has incomparable obligations. One of the key purposes is to give input to national growth and labor market. To contribute in knowledge-based and knowledge driven society, higher education institutions and policy play a critical role. Higher Education System provides innovative skills to the graduates, to help transformation of the society from backward to modern economy through quality teaching, research and innovation. The Pakistan is facing multiple sectors crises such as energy, water and trade deficit. This has thus posed a greater challenge to Pakistan for its position on international economic relations. In this situation the higher education sector needs to play its role to help the country to bring it back to the economic trajectory. Under the Education Sector Reform under different Visions, the Higher Education sector of Pakistan has gone through an overhauling for the last 15 years. There is a protracted mismatch between the higher education and trained labor force which is detrimental to socio-economic transformation. This paper is an attempt to take a stock of these reforms in the education sector for input in innovation to sustain growth on knowledge based economy. My Hypothesis thus would remain that economic transformation of Pakistan is heavily linked with generation of knowledge and therefore Higher Education of Pakistan. This paper intends to correlate the higher education input through overhauling education system of Pakistan vis-à-vis socio-economic transformation of the society.
\end{abstract}

Keywords Higher Education, Educational Reforms, Quality Education, Research and Development

\section{Introduction}

In any country, universities need to be able to carry out two critical roles. First: is knowledge-building, usually through research, analysis, and theory building. Second is imparting knowledge to the next generation through teaching.[1] Developing new knowledge and innovative ideas can lead towards getting intellectual progress. The Higher Education however needs prerequisite of Primary and Secondary supportive platforms which can provide good students for higher education as otherwise just access to the higher education, will become a complex issue and will increase unemployment.

Earlier, in 2002 higher education became an important component of social agenda of Pakistan. It has developed its narrative of strong research and development through inception of Higher Education Commission in Pakistan. The major policy issue of Pakistan was to bring the country on innovation map as Pakistan economic growth had taken off from minus in 1990s to $5.8 \%$ in following years till 2006-07. The Government approved document of Vision 2020 with road map of contribution of higher education in economic development of Pakistan under HEC Mid Term Development Framework. Therefore, the establishment of Higher Education Commission (HEC) reflected the emphasis on the 'improvement and promotion of higher education, research and development in the country. Its Mission statement states: "to facilitate institutions of higher education to serve as engines of growth for the socio-economic development of Pakistan". As per its road map, improvement in quality of academic standards and research is the top priority of HEC. Therefore, considerable efforts have been made in the last few years on improvement in quality. As per QS World Universities Rankings 2010, two universities of Pakistan 
are ranked among the top Technology Universities of the World. However, it is not enough.

\section{Literary Discourse}

The literary debates taken into account from Grace Clark's work on Reform in Higher Education, Higher Education Commission's Medium Term Development Framework, Vision 2020, and 2025 of Ministry of Planning, Development and Reform, Government of Pakistan, Allah Bakhsh Malik's study of 2003 0n The Higher Education in Pakistan, World Bank Country Summery on Education Reform of Pakistan, December 02, 2007 and 2012, Khalid Khattak's Mapping Pakistan Higher Education of 2016, Shah Bano's research on The Role of universities in transforming the economy into knowledge based economy, A case study of Pakistan, 2012, Pakistan Annual Education Action Plan, 2015-2016 and Atta-ur-Rehman's Well done HEC published in The News International in June 2016.

The consulted literature suggests that the role of the Higher Education Commission CHEC) of Pakistan is vital in facilitating and promoting educational research in Pakistani universities through policy analysis as research methodology. The above given studies explored the role of HEC by the analysis of policy provisions, structures and processes developed by HEC to facilitate and promote educational research. Analysis of the data suggests that research is a priority of HEC in its reform agenda for higher education in Pakistan in order to meet the requirements of transformation in society. The above referred studies further highlights that HEC has developed policy provisions, processes and structures that support and facilitate research in Pakistani universities but an overemphasis on scientific research has overshadowed educational research. Availability of funding, a wide range of incentives available for research, faculty development process for research, emphasis on publications and dissemination of research work, access to the global body of knowledge through IT integration and education, and research networks are indication of the effective role played by HEC for the promotion and facilitation of educational research. Research suggests that there exist some hindering factors as well which includes, dependency on donor funding and sustainability issues, communication gap between departments of education at universities and HEC, unavailability of clear policy text for educational research, lesser support provided to the private sector.

\section{Materials and Methods Section}

Pakistan needs to have at least five universities in the top 300 Technology Universities of the World by 2015.[2] Nevertheless, by corresponding the Pakistan socio-economic need and human resource development HEC has focused on following core areas:

1. Faculty development

2. Improving Access

3. Promoting Excellence in Learning and Research

4. Relevance to the Economy and Development

\section{Aspiration of Higher Education in Pakistan and Vision of 2025}

Higher education program cannot be taken in isolation in any society, it needs holistic approach. Therefore, Ministry of Planning and Development, has developed Vision 2025 in 2014 as a road map for putting Pakistan on developmental path. It has particularly emphasized on higher education and research as an engine of growth for future Pakistan and envisaged that "A major thrust will be to put Pakistan on the innovation map of the world through focused research and development."[3] The vision has further envisaged that it will increase Higher Education coverage from $7 \%$ to $12 \%$, and increase number of PhD's from 7,000 to 15,000 and to improve Primary and Secondary Gender Parity Index to 1, and increase female workforce participation rate from $24 \%$ to $45 \%$.[4]

Keeping top priority and the issue of quality education on high political agenda, the Higher Education Commission was significantly strengthened to ensure the quality education, as in the contemporary competitive world, just earning degrees is not enough but a relevant knowledge which can contribute to the economy and can be used as a social capital. Millennium Development Goals (MDGs), were also an international obligation to steer the growth of developing countries in a way that can promote prosperity to the developing word.

Therefore, the role of university became central in generating a knowledge based system to bring country back to economic growth. Research is always considered a most powerful source of creating knowledge. While, the state of research and higher educational institutions was miserable and far from satisfactory and meaningful research which could steer economic growth in country.[5] The state of research was not complementing the objective to be integrated with higher education worldwide also. The major advancement in Higher Education came through the Education Sector Reforms, Strategic Plan 2001-2004 where major shift was made of science and technology. 


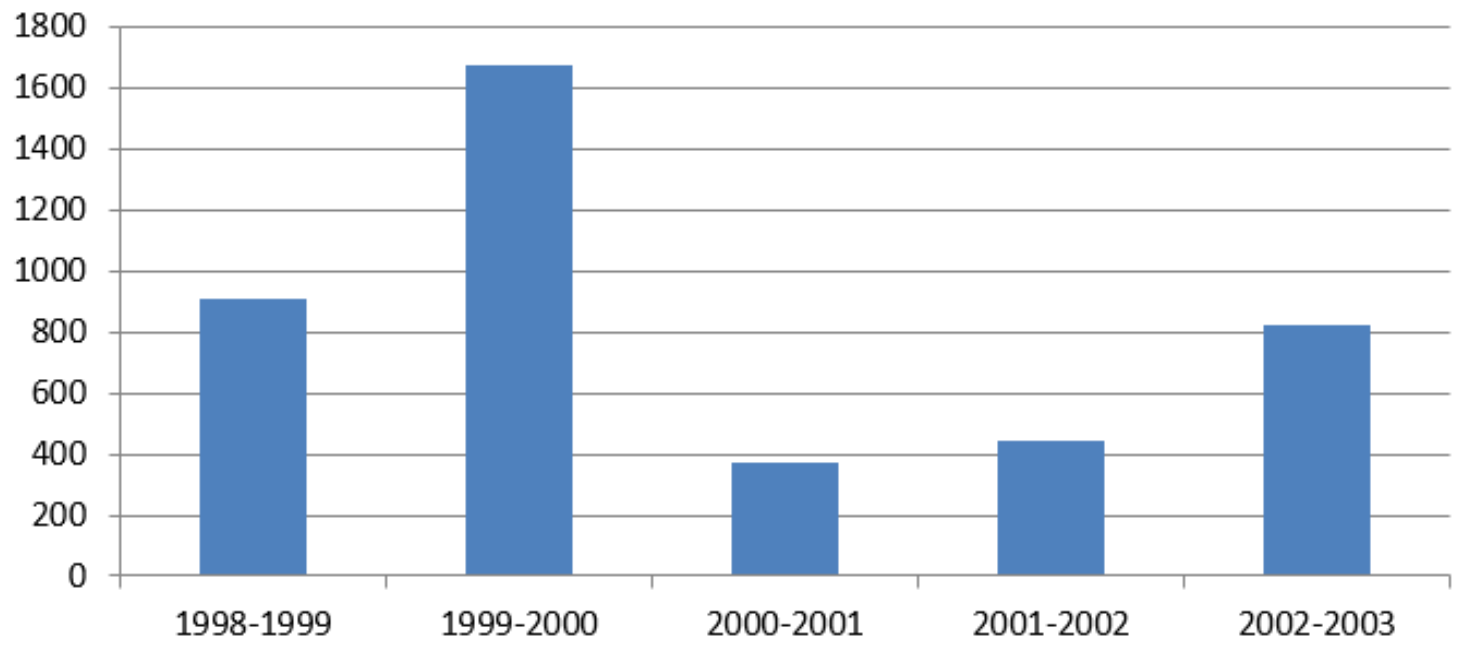

Source: Different Issues of Economic Survey of Pakistan

Figure 1. Development Expenditure of Ministry of education/HEC, and S\&T (In Million)

One of the major reasons of the low input of education was the meager spending on the higher education due to political instability and less economic growth in 1990s in Pakistan. In 2001-2002.the reforms proposed raise in funding from higher education form $0.39 \%$ of GNP to $2 \%$ of GNP, along with the strengthening the service structure for university teachers, laboratories and libraries. This ratio was also lesser comparative in the South Asian region such as India, Maldives, Nepal and Iran. A shift towards more science education was ensured by improvement from Arts to science enrolment from 70: 30 to 50:50 with the provision of introduction of new emerging discipline one of the targets of reforms was to get higher education ratio increased from $2.6 \%$ to $5 \%$ in Pakistan. Thus, realizing the significance of overhauling of the sector, the spending on the higher education was increased as shown in the following graph. The funding on higher education was increased from 910 million Rs (Rupees-Pakistani Currency) in 1999 to 1676 million Rs in 2000 .

HEC after its establishment to complement the increasing demands for social capital, major development mostly focused was on the areas as under [5]:

1. Quality Assurance: For the sake of quality assurance following measures were taken by HEC

i. Establishment of Quality Assurance Agency at the HEC and Quality Enhancement Cell at Higher Educational Institutions.

ii. A program launched to equip both new and existing faculty with the advanced qualifications;

iii. Introduction of a new compensation system (Tenure Track System);

iv. Provision for laboratories, equipment and scientific material.

v. Alignment of academic degrees with international norms; and vi. Curriculum revision.

2. Access: To boost demand and expand supply following measure taken to ensure access of education:

i. Expansion of existing infrastructure.

ii. Exploitation of the potential of distance learning; and

iii. Provision of undergraduate and post-graduate scholarships to students in both the public and private sectors.

3. Governance: The Education sector of Pakistan was suffering for long time of poor governance due to low political agenda on national level. The reforms to overhaul this sector made efforts and took measures in order to have effective governance. Strengthening capacity of HEC through streamlining of financial management and procurement procedures, and stakeholder consultations.

In addition to this, other measures have been taken to address the emerging demand generated by the private sector. The culture of accountability for the universities was also introduced for quality assurance for a generation to get ready for the challenges of $21^{\text {st }}$ century. HEC has boosted the capacity of faculty members through the funding of higher education from international institutions also. This has brought a greater shift in higher education of Pakistan. For instance as per a report from 1947 to 2014, Pakistan's higher education institutes (HEIs) produced 11,988 PhDs. As of 2014, Pakistan, had student enrollment of 1.4 million, including over 900 foreign students and Afghan refugees, studying in various HEIs. Most of the $\mathrm{PhDs}, 1,541$, were produced in Language and Literature, followed by 1,462 in Chemistry and 933 in Agriculture. Up to the year 2014, the country's HEIs had produced only 500 $\mathrm{PhDs}$ in Engineering and Technology while $908 \mathrm{PhDs}$ were 
awarded in Religious Studies. Reforms in Higher Education brought huge impact in enrollment which grew around $21 \%$ annually. Following chart reflects number of PhDs in Pakistan before and after establishment of higher education commission which shows that pre-HEC the number of PhDs was very low as compared to post HEC establishment. Similarly the Educational overhaul reforms have given rise to the investment of the private sector in the education sector, particularly the higher education. The graph shows speedy rise in the private sector universities and so as the higher education degrees. This brought a very positive impact on Education overhaul system in Pakistan.[7]

Since the eminence of the higher education in Pakistan was very low in the past, in terms of qualifications of teachers, standards of publications and participation of research papers in international research organization, conferences and seminars by Pakistani authors, teaching excellence etc. Only $25 \%$ of the total faculty was having $\mathrm{PhD}$ degree, which was a serious hindrance towards quality enhancement of the higher education reforms and HEC future objective to establish universities as research centers for producing knowledge to complement its role in socio-economic development of Pakistan, keeping this in view, the Quality Assurance Cells under the scope of the quality assurance of HEC. The faculty members related to the certain discipline where Pakistani universities were lacking, have been encouraged from abroad to set certain benchmark and criterion for quality teaching. On the other side, over the time HEC has encouraged the Pakistan researcher to compete for international education and research, and has been facilitator as well as providing funds to get quality faculty members back in the country for preparation of next generation in Pakistan. Over the years, the HEC has tried to play the role of providing required environment to universities to grow and become research-led universities.

For creation of new knowledge as well as contribution in the research of science and technology, science education, evolving think tanks and creation of researcher who can help in solving the problems of Pakistan have been focused. Keeping this in view all over the Pakistan, 45 research institutes were established from 2010 onwards for generation of new ideas through research and development. Resultantly, total 73 patents been filed by the Pakistani research institutes and universities. As per Higher Education Commission figures, around 2450 research students are carrying their research out of them around 500 are working in the field of humanities and social sciences and rest are in the Engineering and technology, physical sciences, Business Education and Agriculture and Vet Science. This shows the trend and interest of the students towards development of science and technology field which is most desired for the modern economy. Following images reflects the distribution of the Pakistani researcher around the world from the developed institutions of the world. Where, around 8000 students are now getting higher educational degrees from 36 countries, out which 1341 student are engaged in research in United States.

Number of PhDs in Pakistan

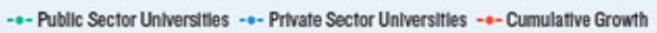

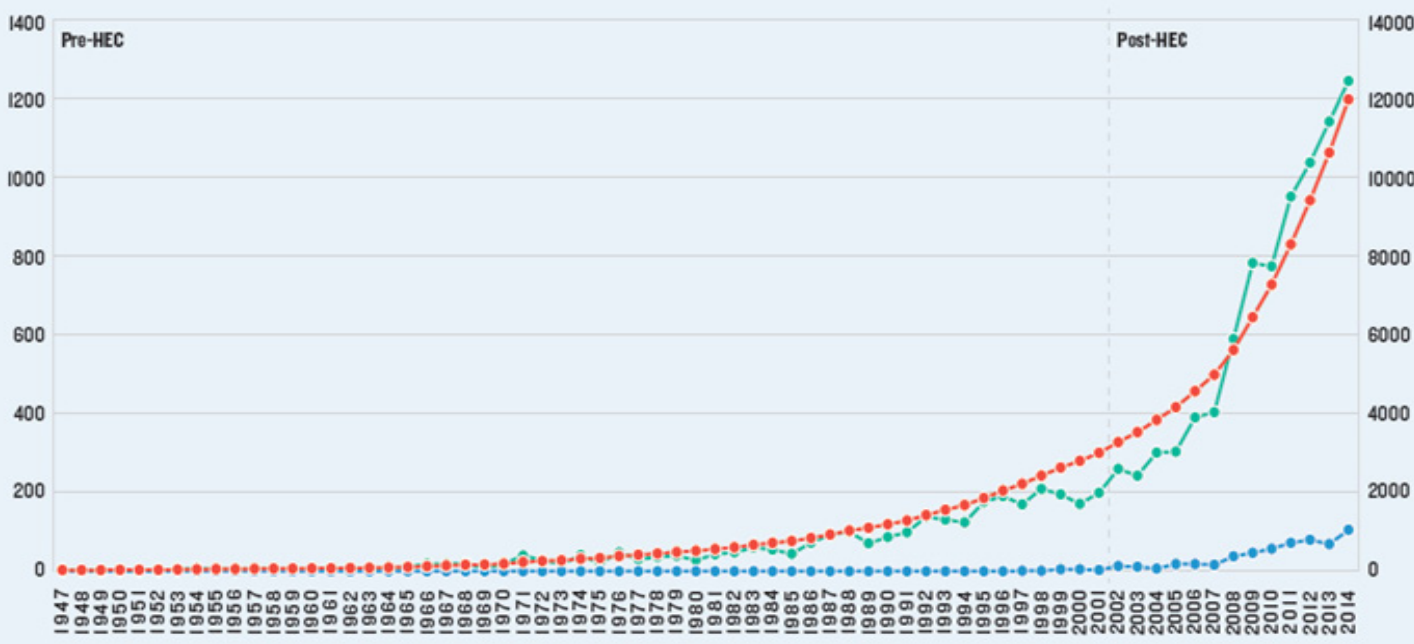

Source: Higher Education Commission

Figure 2. Positive Impact on Education Overhaul System in Pakistan 


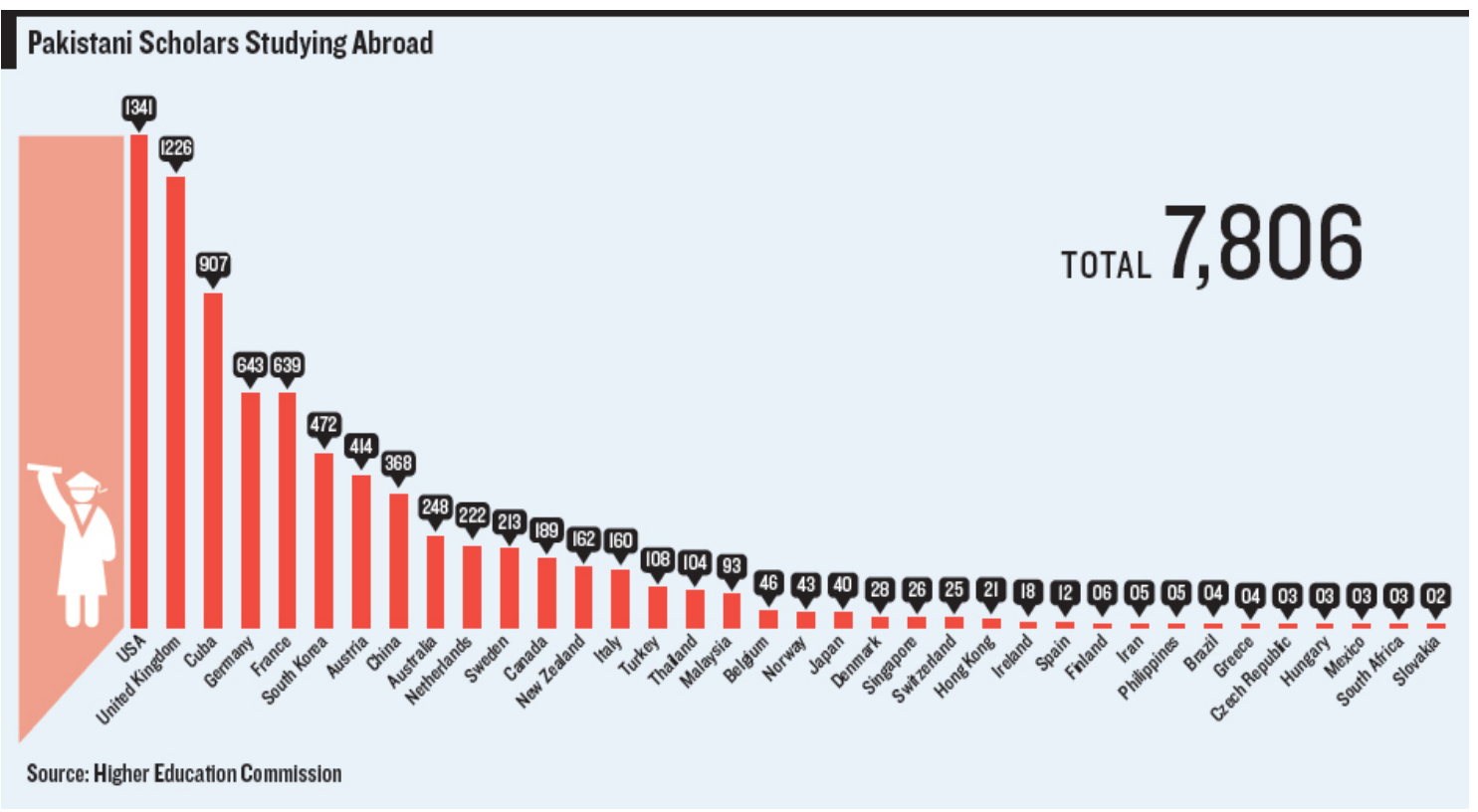

Figure 3. Pakistani Student are Engaged in Research in United States

\begin{tabular}{|lrrr|}
\hline \multirow{2}{*}{ Indicator } & \multicolumn{2}{c}{ Target } & \multicolumn{2}{c|}{ Achievement } \\
\cline { 2 - 5 } & Number & Number & \multicolumn{1}{c|}{ Percent } \\
\hline Impact factor journal publications & 12,500 & 7,141 & 57.13 \\
\hline Establishment of ORICs & 75 & 39 & 52.00 \\
\hline Establishment of technology incubators & 60 & 47 & 78.33 \\
\hline Centers for Advanced Studies & 4 & 4 & 100.00 \\
\hline
\end{tabular}

Figure 4. Technology Incubators

How to measure out the performance of the universities was a challenge to be proof by the overhauling system of the education sector. For this purpose, the Quality Assurance centers were established as mentioned above and also publication were standardized which is indicated in the international organization such as QS and also standard indicators of the universities ranking around the world. This mainly includes, class room environment, teaching method, research and publication of the faculty as per given standards by the HEC.

The Cabinet Division, government of Pakistan through these reforms has categorized the publication under the $\mathrm{W}, \mathrm{X}, \mathrm{Y}, \mathrm{Z}$ classification, for performance evaluation of the researchers. There is greater attention given to the appointment of Vice Chancellor, of the universities and merit should be observed without the political interferences to ensure the quality issues in the universities. HEC need to ensure not only that the quality is maintained at a minimally acceptable level it also needs to enhance quality to keep the higher education system in Pakistan competitive and reactive to changes in the external environment.

Resultantly out of 877 publications indexed in the ISI Web of Knowledge in the year 2001, Pakistan had 8,163 publications indexed in the Web of Knowledge by the year
2014.

To make Pakistani research international recognized and competitive which can be good source for knowledge economy of Pakistan, HEC has significantly focused on the research and innovation for promotion of entrepreneurship development. As per performance standards benchmark for innovative publication, HEC has set target of 12,500, impact factor Journal Publication, where are $57 \%$ of it was attained by 2015 , whereas centers of the advance studies were achieved as per the target and 47 technology incubators were established by the 2015.

Though the Higher Education Institutions are growing however, still the biggest question arises of its relevance with the emerging needs of industry and market. Particularly after the investment in Pakistan from China and Pakistan initiative through CPEC, that whether the present ratio of research and development in the higher studies would be able to meet the challenge of the knowledge worker in the CPEC projects. A study on the higher education of Pakistan and access to the university education shows the access to higher education ratio which is important to take cognizant of, in the context of preparation of the youth for the emerging market consumption vis-à-vis CPEC. The following figures 
shows that only 1.8 percent of the youth had access to the higher education in 2001 out of 23.1 million youth of Pakistan. This ratio is improved by 2015 and it seems improving considerably by 2020, after reforms for overhauling the education system has started in 2001 onwards.[8]

It is firm believe in academia that universities should enjoy freedom and autonomy and should be seen as research centers to give input in policy arena and contribute generally in development. In such a way it can match itself with the reforms and also with the HEC's vision of higher education learning and promoting culture of research and development.

\section{Securing Development through Research}

Since 2002, the HEC tried to make certain headways, to improve teaching, enrolment, and access to education particularly higher education. However still Pakistan is not able to position its universities on good ranking in the global ranking, there is still much needed to be done. In this context, if we look at the following table, this shows that lot has to be done to ensure quality education in Pakistan to catch-up even in the region on account of global ranking of Pakistani university.

\begin{tabular}{|lr|}
\hline Country & $\begin{array}{r}\text { No. of universities in } \\
\text { 701+ category }\end{array}$ \\
\hline China & 28 \\
\hline India & 12 \\
\hline Turkey & 10 \\
\hline Pakistan & 05 \\
\hline Iran & 02 \\
\hline Sri Lanka & 02 \\
\hline Bangladesh & 01 \\
\hline Nepal & 00 \\
\hline
\end{tabular}

Source: (PAEP, 2016).

Figure 5. Number of Pakistani Universities in Global Ranking
Similarly if we look at the growth of the universities for promoting higher education through its overhauling system the following table, that in 2004-5, Pakistan, public and private universities were only 110 with 471,964 whereas after input of government policy of higher education, there were 163 universities with phenomenal growth of access of higher education $1,400,000$ enrolment. The higher education intuitions are established throughout the country and region of the country, so that maximum access can be assured.

Gender approach has been the main element of the overhauling of education system of Pakistan. Traditionally, the women education has not been priority in Pakistan, as they are considered to do the house chorus even after being educated, working outside house was not much allowed in Pakistani society, however since the change in socio-economic dynamics keeping in view the international trends of women participation in economic development, Pakistan higher education policy has specially focused on gender based enrollment increase in higher education.

The trend of increase in women enrollment (573.53 percent) is significantly higher than that of men enrollment (409.77\%) at HEIs during the last 15 years. The possible reasons for the as per the assessment of higher Education policy includes decreasing discrimination against girls in families and women own aspiration to obtain tertiary degrees and last but not least is the feminization of the teaching profession and learning environment more conducive to girls, social and cognitive disposition. More number of women teachers in higher education is encouraging the parents to the certain level to send their girls for higher education and this argument can be substantiated with the fact that International Islamic University has a kind of segregation of the two campuses, for male and for female. The enrolled number of students is almost the same, as certain families still prefer their girl to be education through female faculty, which at least can give a chance to the girl to complete her higher education.

\begin{tabular}{|lrrrr|}
\hline Year & $\begin{array}{c}\text { Universities/Degree Awarding Institutions } \\
\text { Public }\end{array}$ & Private & Total & $\begin{array}{r}\text { Student } \\
\text { Enrolment }\end{array}$ \\
\hline $2004-05$ & 57 & 53 & 110 & 471,964 \\
\hline $2008-09$ & 70 & 57 & 127 & 803,507 \\
\hline $2012-13$ & 87 & 66 & 153 & $1,080,000$ \\
\hline $2013-14$ & 87 & 69 & 156 & $1,230,000$ \\
\hline $2014-15$ & 94 & 69 & 163 & $1,400,000$ \\
\hline
\end{tabular}

Source: (PAEP, 2016)

Figure 6. Universities and Degree Awarding Institutions in Pakistan 


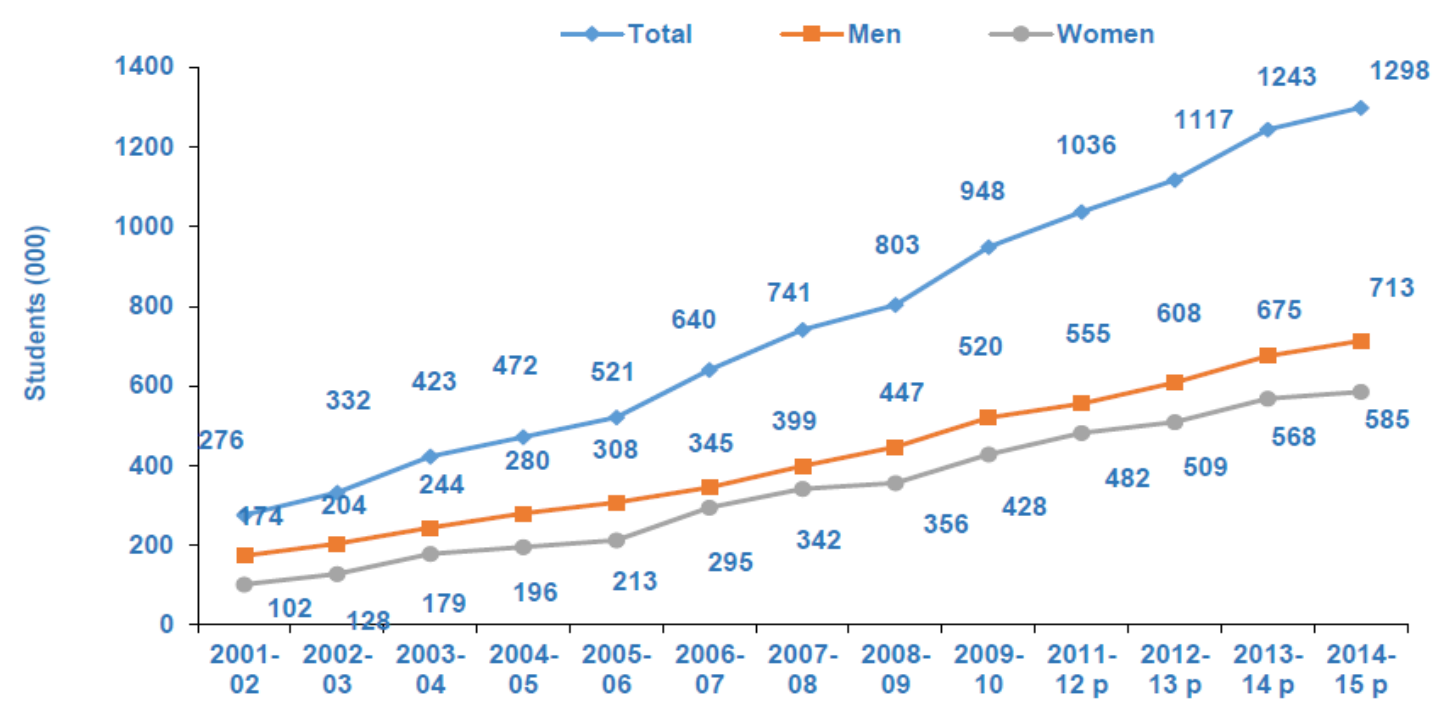

Figure 7. Enrollment at University (Campus + Constituent Colleges) 2001 to 2015

\begin{tabular}{|c|c|c|c|}
\hline \multirow[t]{2}{*}{ Indicator } & Target & \multicolumn{2}{|c|}{ Achievement } \\
\hline & Number & Number & Percent \\
\hline Impact factor journal publications & 12,500 & 7,141 & 57.13 \\
\hline Establishment of ORICs & 75 & 39 & 52.00 \\
\hline Establishment of technology incubators & 60 & 47 & 78.33 \\
\hline Centers for Advanced Studies & 4 & 4 & 100.00 \\
\hline
\end{tabular}

Source: (PAEP, 2016)

Figure 8. Research and Publications

The biggest challenge Higher Education Policy is facing is the relevance of the education with the knowledge based economy. Though as mentioned above the students enrolment is increasing but they are not relevant to the job market. Pakistan's policy makers are very much concerned now about the absorption of the investment of CPEC in Pakistan and how the youth should be prepared to be consumed in the Chinese companies. Nevertheless, HEC in in their planning has taken some encouraging steps by revising the curricula to cater the need of the skill based graduates in Pakistan. It also supported research pertaining to the socio-economic needs of the region in the vicinity of the university through supporting and expanding on the establishment of Business Incubation Centers (BICs). HEC also introduced Small Business Innovation Research (SBIR) grants to support relevant research at the university which are partnered with the industry. HEC is pursuing the policy to develop a research culture because research culture is more important to bring new ideas and innovation because only incentives may not help in case the research environment is not created. In order to establish center for excellence to promote international standard research, HEC has been to achieve more than $50 \%$ of his target. The following figures show that Impact factor Journal Publications, which shows an international standards research and innovation Pakistani universities produced 7,141 papers till 2015, similarly other targets are met closely and center of Advance Studies target is met $100 \%$. However Impact factor journal which is a in-depth research product of the faculty members is still low and normally it is done only for the purpose of promotion and paper presentation in international conferences, otherwise the routine activity of the faculty is teaching and load of the faculty do not allow them to go for quality research which need time and money also. The research grant is available through different research projects but that procedure is some cumbersome and lengthy that faculty do not feel comfortable applying for the research grant, therefore, it lessens the chances further of the quality research. Though target of HEC seems to be ambitious however, it is achievable provided other factors of under production of research ideas are addressed.

There are certain areas which is lacking in the university education, such as critical thinking due to lack of culture of debates and discourses. Normally agreeing with the ideas of others is the tradition, whereas generating an alternate idea demands a disagreement amicable. There is lack of trained faculty members in certain research areas in which they are supervising. Fresh $\mathrm{PhD}$ holders are also supervising on the area which is new for them, should be discouraged. The research topics and 
ideas have disconnection with overall country strategy of development requirement. It is mostly based on the individual own choice to meet the requirement of the future promotion etc. Moreover the research coordination is also lacking between the different departments of the same discipline of the university as well as intra-university research coordination which can give a road map of research areas if coordinated properly.[9]

\section{Analysis: Challenges of the transformation through Higher Education in Pakistan:}

Since 1980s the higher education were on the road map of adopting the market oriented approach for gaining efficiently in economic growth and mostly developing are transforming the Higher Education sector. Institutional autonomy though remained a bigger challenge in the sector, as higher education is essentially a public good and much role of the government is justified. Nevertheless government can fail in bringing the technology driven reform and society.

Taking an account of HEC efforts, over the period of 15 years considerable changes have been taken place in the higher education of Pakistan, and the result of higher education reform can be seen in the trust of parents and stakeholders that Pakistani universities can also perform better and produce world class papers and bring universities at par with those of developed countries. The total enrolment in the universities, i.e., at post graduate stage, is 1.355 million. Out of this enrolment 1.141 million (84\%) students are enrolled in public universities, whereas, 0.214 million $16 \%$ ) students are studying in private universities. Despite the fact that there are more universities in public sector there are less students in these universities as compare of private sector. The total male enrolment in the universities is 0.753 million (56\%), whereas, the female enrolment is 0.602 million (44\%). The total teachers in the universities are 83,375 out of which $66,532(80 \%)$ are in public and $16,843(20 \%)$ are in private sector.[10] The overhauling of higher education by government of Pakistan has been successfully was able to build a narrative of research and development. However as mentioned above the higher education reform and commission is not working in vacuum, this is part of the institution working in the country and can get affected by the whole system of the society. There are certain issues related to capacity building, governance and above all the higher education in Pakistan is still not high on political agenda despite the linkages and of economic growth and university is very much established in the government all short and long term plans whereas the markets have already the absorption issues of the university graduates. Our global positioning in innovation is already low which caused a greater determination of the government to pay attention to the following issues for transforming the Pakistani society to be able to become an economic power in South Asia. The decline in standards of research and innovation has been core to the HEC policies. HEC in its MTDF (2011-2015) has identified the certain issues in higher education of Pakistan, which generated a need of overhauling in Pakistan's Higher Education, recognized as one of the engines of economic development, and offered a long-term vision and an ambitious strategy, which the HEC has begun to implement. Broadly HEC have been working through these years on its core areas of, faculty development, improving access, promoting excellence in learning and research, relevance to the Economy and Development.[11] As per discussion above, the overhauling of education and its linkages with industry was long due for the transformation of the society. HEC through its robust policy has made efforts to establish a competitive and dynamic higher education in Pakistan over last 15 years. As a result, Pakistan has been acknowledged for its scholarship by international community and institutions. There are many universities which are competing globally in Pakistan presently. [12]

Gender balance was a greater challenge always in Pakistan education sector, now female student ratio is 46 and 54 in higher education and many girls from rural background also being encouraged in the universities. However, standard remained the core area of governance of higher education commission, as per the outgoing chairman of Higher Education Commission, he has stopped $110 \mathrm{PhD}$ programs in various public and private universities due to quality issues and claimed that HEC will not compromise on academic corruption despite all the pressures the national institution had to face from influential quarters. He further added that "we are working on various partnerships and improving the overall standard of education in Pakistan rather than focusing on the numbers game. Numbers don't mean anything if the students are not well equipped for the professional life as the race for rankings and impact factor is of no use if the real impact of knowledge creation is absent".[13]HEC has acquired international engineering membership with the combine efforts of Pakistan Engineering Council (PEC). Now the engineering graduates from Pakistan can get a job anywhere in the world without going through any additional exam for accreditation in other countries. HEC also won the ' $3 \mathrm{G}$ - Global Good Governance - Excellence in Higher Education Award 2016' in recognition of its outstanding services and good governance systems for development of higher education sector in Pakistan. The HEC thus became the only government organization to be recognized this way for excellence by external international experts.[14] Though keeping in view the overall institutional performance which is widespread corruption in governmental institution such success of $\mathrm{HEC}$ is commendable.

Perhaps the most important factor that led to the HEC winning the global award was its emphasis on quality in all spheres of its activities. An independent detailed review carried out by USAID reflected this aspect in the 
following remarks:

"One of the most striking aspects of HEC since its inception is the emphasis on excellence and high quality in every sphere of its activities. Expectations were set high from the outset. Quality goal targets were set as international standards and expectations. Faculty promotions, publications, $\mathrm{PhD}$ dissertations, research grants, and many of the HEC programs were subject to these standards including evaluation by external peer reviewers...In keeping with its focus on quality, the attitude of the leadership of the HEC was that 'quality is much more important than quantity

No denial of the fact that the HEC has been a success story but yet education sector need improvement on certain account particularly it's linkages with the industry, labor force input from higher education and graduates hired by the international companies, requires more contribution towards innovation, more release of funds ratio vis-à-vis GDP and quality assurance and capacity issues.

Access\& Equities: There is further need of equitable access of education otherwise in coming few years the bigger cities will have more graduates and remote areas will not have share of development. The Campuses must be developing in rural and under developed areas of Pakistan. Inequities due to area distribution of these institutions can be a barrier to entry and opportunity to the education. These inequities are exacerbated further in inequitable distribution of opportunity for students and then labor force.

Quality assurance: It is the core area the HEC is facing severs challenge in brining innovation to the national growth. The categorization of journals has inherent flaws in publications vis-à-vis quality product. It is disconnect with the prevailing society intuitional setup. That is reason why there is greater concerned that despite there are $12000 \mathrm{PhD}$ researcher has been produced during last 15 years, mostly from science and technology but are not contributing in innovation and research, because motivation behind these publication is not genuinely research but the quantity for the sake of career development and particularly this more true for the faculty and researcher on Tenure Track System.

Institutional Autonomy\& Innovation: Institutional Autonomy is an important factor to bring merit and innovation to any society, little or no autonomy generates impediment in tailoring program according to the need of the people and particularly according to the overall country strategy. The intuitions of higher education are the major stakeholders in the dominion of the education. There is considerable research available highlighting the importance of autonomy vis-a-vis innovation and in the first instance at least mincing the original product and creation of world class universities. The patent vis-à-vis university funds also has been researched by the same authors and they were of the view that universities more innovation and patents when they face completion and have more autonomy.

As otherwise the political interference in policy and appointment of Administrative Authorities can hamper performance badly. That is obvious from the fact that despite HEC funding for pursing $\mathrm{PhD}$ degree from international institution abroad is not bringing innovation to Pakistan. Even every year HEC is sponsoring 1000 $\mathrm{PhD}$ indigenously, the question is why they are not much productive in innovative ideas.

Demand side Responsibility: In the backdrop of transformation and impact of higher education, HEIs are pervasively lacking capacity to respond to the markets in their emerging needs, the relevance of quality to teach and to research. This shows a public discontent particularly regarding education. It's disconnect undermines the reforms itself. Academic faculty has a precarious role in skill development. They are key incubators of the innovation and creativity that will enhance national productivity and competitiveness. [15] The research \& higher education student who can be greater source of the innovation have fallen prey of grade inflation instead of applying mind. Now grade ' $A$ ' is a very common as compared to 20 years ago when mostly the ' $\mathrm{B}$ ' and ' $\mathrm{C}$ ' were the most common grade and ' $\mathrm{A}$ ' was rare due to standard and now grade inflation is teaching exactly opposite of using innovative ideas. Through this paper, the research intends to predict of consequences of the inflated grades by the professors, it is brining alarming low quality in higher education and research output of the universities.

These are governing issues mostly on the supply side, but demand side as mentioned above is equally responsible for a gap and disconnects of higher education with innovative contribution and with industry. It is responsibility of university professor to be careful of inflated grades as it is not only discouraging the critical thinking of the students as they are rewarded without any much effect but also devaluing the value of transcript as well as in job market. We see now more graduates and decline in standards for consumption in the companies. That's is reason that parents thinks that higher education in Pakistan is overpriced with poor quality, and had become a simple commodity. In this scenario the universities and HEIs have to bear more responsibility that any other institution. Universities and research centers need to promote themselves and create an environment of vigor. No doubt too many universities are establishing in public and private sector as a result of vigorous education sector reforms, and HEC overhauling however, these are demanding too little from student and particularly on innovative approach. Student attitude towards grades needs to be changed drastically, mostly student very much reluctant to accept grade less than A and B or less becomes devastating for them. More grade inflation has turned students in to panic and they are paradoxically 
performing less. The idea behind inflated grades may be for crowding in students but these cannot be consumed in the market as industry wants innovation and not only look good on paper and feeling successful. Today for the professors due to this era of $\mathrm{A}$, is becoming very difficult to distinct between mediocre and best student.

Nevertheless, transformation through education is neither completely in the capacity of HEC nor the university, but the high political agenda and government will is important above all, as funding and governance is a major hindrance of innovation and restore standard.

Mismatch of demand and Supply for Industry: A University curriculum is not above to respond the industry, as they have very less information from the industry that what kind of skill graduate they want to absorbed. No input channel from industry is available in most of the public sector university in Pakistan. No tracking system of the employment outcome of the university student is available normally for the university graduates. This creates a mismatch of supply and demand of university graduate. This information gap has a detrimental effect on diversification of the research and innovation as university cannot review their curricula and teaching method to equip students well to harness the job. The countries like China and Malaysia have strong university and industry links and have a higher share of innovation in the national growth.

Horizontal Disconnect between the institutions: Higher Education Institutions as well as research center themselves have absence of coordination. In this way the research is being conducted in isolation and not much connected with each other in education sector and also not known to the industry. This ultimately results in low input of research and sometime repletion of the same kind of research.

Feeble incentives innovation: In case the sufficient capacity is available in the faculty to teach innovation and support it but then issue comes of lack or weak incentive system for higher education institutions to produce. This can impede the innovation as private sector some time is more incentivized. Public institutions do focus on the grades but not much on the outcome of the education process in terms of rewarding the innovation.

Vertical Disconnect between Primary, Secondary and Higher Education: The Education sector reforms are too much focused on higher education with the purpose to get more innovation and more contribution in national development to implement the government road of different long term vision of planning ministry of Government of Pakistan. However overlooking the primary and secondary would have strong impact on the higher education input and outcome of the higher education also. This shows a non-comprehensive vision of higher education sector. The weak linkage of higher education with secondary is an area to be focused.

Building peace and stability for sustainable development: Universities are producing knowledge but above all they are preparing humans to live in this world together. One of the aspects of the transformation is bringing peace to the society to sustain economic development. This is high time for Pakistan to bring changes in academic curricula also at graduation level. The Education system through such reforms must transmit the message of peace and must be in harmony of overall economic agenda of Government, and understanding how to respect the culture national and international level. Creation of responsible is obligatory on the Higher Education system.

\section{Conclusions}

The Higher Education Commission (HEC) is striving to promote the quality research in Pakistan to deal with the challenges of socio-political and economic transformation within the society and across the globe. For this HEC is committed to the Sustainable Development Goals (SDGs) process and feels a special sense of responsibility to incorporate the SDGs process into academic activities in Pakistan, because the SDGs are meant to lift up the downtrodden communities, pulling them out of poverty and paucity of education. HEC is working dedicatedly to achieve major objectives including progress on increased access, quality and relevance. Since the inception of HEC, the access rate has increased from 2.5 per cent to 10 per cent and HEC is actively working on improvement in quality and relevance. HEC values international collaborations for promotion of higher education and research in the country. HEC has developed a number of collaborations with various countries including the United States, China and the United Kingdom. He stated that the SDGs are meant to lift up the downtrodden communities, pulling them out of poverty and paucity of education. He maintained that HEC plans to establish a regional research fund to promote research culture at grass root level which will help people of different districts of Pakistan find solutions to their local problems. The Chairman stressed the need for mobilising masses to work on ignored issues which could help resolve their local problems. "HEC will encourage regional universities or university campuses in districts to collect database and identify challenges and opportunities for research. This Research with 'small $r$ ' will prove to be very effective in addressing local socio-economic issues," he affirmed.

In the backdrop of above given analysis taking stock of overhauling of higher education in Pakistan the developed Hypothesis of the study stands correct. On basis of the discussion in materials and methods section the following conclusion can be drawn:

First: The International economic order and stringent polices of economic institutions have pushed a rigorous approach in which Pakistani universities were used to 
operate, teach and research. Innovation is the key of success of economic system of Pakistan.

Second: Higher Education Commission of Pakistan has played a pivotal role in the brining tremendous growth in higher education however to relate it with transformational changes of the society will still take a long way.

Third: Consultation with stakeholders including the research companies and research users is critically important for universities to do. A constant training of faculty on the new concepts and methods of teaching is a must to produce the innovative ideas.

However, based on the findings, the study recommends development of indigenous funding strategy, enhanced collaboration and participation of universities through communicative structures, an increase in educational research funding, enhanced facilitation to private sector and wide range of evaluative studies to be carried out to review policy provisions and structural changes to facilitate educational research in Pakistani universities.

\section{REFERENCES}

[1] Grace Clark, Reform in Higher Education in in (Ed) by Robert M. Hathaway, Education Reform in Pakistan Building for the Future, Woodrow Wilson, International Centre for Scholars.

[2] Higher Education Commission (HEC) Medium Term Development Framework II http://planipolis.iiep.unesco.or $\mathrm{g} /$ sites/planipolis/files/ressources/pakistan_higher_educatio n medium term development framework 2011-2015.pdf Midterm Development Framework, 2011-Ḧigher Education Medium Term Development Framework, Op,cit.

[3] Vision 2020, Ministry of Planning, Development and Reform, Government of Pakistan. https://www.pc.gov.pk/vi sion/visiondoc

[4] Vision 2025, Ministry of Planning, Development and
Reform, Government of Pakistan. https://www.pc.gov.pk/vi sion/visiondoc

[5] Allah Bakhsh Malik, The Higher Education in Pakistan, Maqbool Academy, Lahore, 2003.

[6] World Bank country Summery on Education Reform of Pakistan, December 02, 2007. http://siteresources.worldban k.org/EDUCATION/Resources/278200-1121703274255/14 39264-1193249163062/Pakistan_countrySummary.pdf

[7] Khalid Khattak, Mapping Pakistan Higher Education, MIT Technology Review Online report, http://www.technologyr eview.pk/mapping-higher-education-in-pakistan/, February 10,2016

[8] Shah Bano, The Role of universities in transforming the economy into knowledge based economy, A case study of Pakistan, An Unpublished Doctoral Thesis, Faculty of Business and Law, University of Southampton, 2012.

[9] Pakistan Annual Education Action Plan, 2015-2016.

[10] Pakistan Education Statistics, 2015-16, National Education Management Information System Academy of Educational Planning, Ministry of Federal Education and Professional Training, Government of Pakistan.

[11] Grace Clark, Reform in Higher Education in in (Ed) by Robert M. Hathaway, Education Reform in Pakistan Building for the Future, Woodrow Wilson, International Centre for Scholars.

[12] Khalid Mahmood, (2016), HEC MTDF-II: Study Report Overall assessment of the higher education sector, Higher Education Commission of Pakistan.

[13] Mukhtar Ahmed, chairman, Higher Education Commission (HEC) of Pakistan, shared these thoughts in his lecture delivered at the Institute of Policy Studies (IPS), Islamabad on September 12, 2017.www.ips.org.pk

[14] Atta-ur-Rehman, Well done HEC, The News International, June 22, 2016

[15] World Bank. 2012. Putting Higher Education to Work: Skills and Research for Growth in East Asia. World Bank East Asia and Pacific Regional Report. World Bank. C) World Bank. https://openknowledge.worldbank.org/handle/ 10986/2364 License: CC BY 3.0 IGO.” 